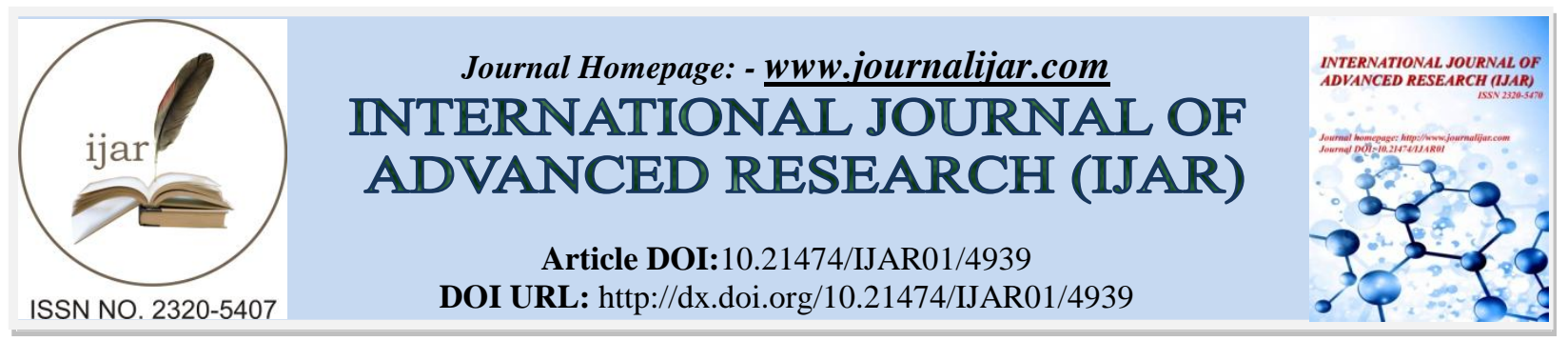

RESEARCH ARTICLE

\title{
SELF-EMPLOYMENT PROGRAMMES IN INDIA: A JOURNEY FROM INTEGRATED RURAL DEVELOPMENT PROGRAMME (IRDP) TO NATIONAL RURAL LIVELIHOOD MISSION (NRLM).
}

Abhisek Mishra.

Ph.D. Research ScholarDepartment of Business Administration, Sambalpur University.

\section{Manuscript Info}

Manuscript History

Received: 24 May 2017

Final Accepted: 26 June 2017

Published: July 2017

Key words:-

IRDP, SGSY, NRLM, Poverty

alleviation, Self-employment

\section{Abstract}

Poverty reduction has remained the central concern in India. The trend of introduction of self-employment programmes as a policy tool to fight against poverty is found in India. This paper critically reviews different self-employment programmes introduced in India. It covers Integrated Rural Development Programme (IRDP), Swarnajayanti Gram Swarozgar Yojana (SGSY) and National Rural Livelihood Mission (NRLM). The paper further explains how the approaches of the Government have changed across the time (explaining merits and demerits of each programme) to fight against poverty. The paper concludes how the current self-employment programme is better in comparison to previous programmes.

Copy Right, IJAR, 2017,. All rights reserved.

\section{Introduction:-}

In the post-independence India, policies to alleviate poverty had come to assume vital importance (Haragopal\&Balaramulu, 1989). The poverty alleviation programmes are classified into self-employment, wage employment, food security and social security programmes (Yesudian, 2007). The present is concerned with a selfemployment programme. Thus, a review on different self-employment programmes introduced by GOI is presented below.

In the year 1980, Government of India (GOI) introduced a credit based, self-employment poverty alleviation programme in the name of Integrated Rural Development Programme (IRDP) along with some allied programmes to fight against poverty (Kalpana, 2011). Under this, GOI targeted below poverty line (BPL) families by providing loans to purchase assets by subsidising the cost of those assets.

Bagchee (1987) highlights four major evaluation studies of IRDP (i.e., evaluation report of IRDP by Programme Evaluation Organisation, PEO study; study of IRDP by Reserve Bank of India, study of IRDP by National Bank for Agriculture and Rural Development \& the economic assessment of poverty eradication and rural unemployment alleviation programme and their prospects by Institute for Financial Management and Research, IFMR study) with an all-India coverage.

The above studies concluded that the impact of IRDP remains unsatisfactory and there was the need to make it more effective; as only forty percent of the beneficiaries crossed the poverty line in a liberal scale. In the context of liberal scaling, Subbarao (1985) points out that considering the criterion for crossing the poverty line as the primary index of the programme and judging the programme through the index is not a correct one. 
In addition to the above, different studies on IRDP highlight the limitations of IRDP including lack of cooperation among aiding agencies (Krishna, 1983), non-utilisation of funds (Paul, 1984), complicated rules and regulations (Ramreddy\&Haragopal, 1984), weak planning (Hirway, 1985), lack of infrastructural facilities (Sanwal, 1985), lack of inter-sectoral linkages (GOI, 1985), involvement of middle men (Ramreddy\&Haragopal, 1985), regional imbalance in the distribution of funds (Rao, 1986), lack of interest from bureaucrats (Desai, 1987), involvement of unqualified and unskilled staff at various levels (Bagchee, 1987) and delay in the implementation of the scheme (Saxena, 1987).

The above limitations of IRDP compelled the Government to implement a comprehensive group based scheme (complimenting multiple employment generation programmes) in the name of SwarnaJayanti Gram SwarzagarYojana (SGSY) in April 1999 (Kalpana, 2011). Considering the non-viability of the enterprise of poor individuals and their poor credit worthiness SGSY follows a bank linkage model, where SHGs are formed and financed by banks (Yesudian, 2007; Ray, 2008). The programme adopts a poverty lending approach for poor due to minimal credit (Robinson, 2001). As per Radhakrishna committee report (further mention as RRC), the performance of the programme is found good in the states of Andhrapradesh, Kerala, Nagaland, Manipur and Assam (Dasgupta, 2009). Badodiya, Tomar, Patel and Daipuria (2012) identify a positive impact of the programme in respect of monetary gain. Increase in 55.38\% of total cropped areas (Baghel, 2003) and increase in income of beneficiaries, engaged in diary (Meshram et al. 2005) are found after the introduction of the programme.

SGSY too goes through several limitations. Mosse (2004)shows that the practical orientation of the programme was not based on theory, as it was implemented by collaborating agencies with a strong vertical control. The complicated process of getting credit, short duration of repayment of loan, non-availability of programme related information and problems faced by the beneficiaries in filling the bank application form are identified as major problems of the programme (Dhakad\&Khedkar 2014). The RRC observes (i) only one fourth of the beneficiaries engage themselves in income generating activities, (ii) the foundation of the SHG programme seems to be very weak, as the beneficiaries leave this after receiving the revolving fund, (iii) beneficiaries who clears the grade II test seem to wait for longer period of time for availing loan and subsidy amount (Dasgupta, 2009). Further, weakness in the credit delivery system is identified by RRC. As an important feature SHG lending, bank branches follow traditional approach instead of microfinance approach. Therefore, for tackling the basic illness of poverty, the committee recommends shifting from self-employment strategy to wage-employment approach and opening of more rural branches paying a uniform rate of interest of $7 \%$ per annum with the government subsidising the bank for the shortfall (Dasgupta, 2009). The RRC also recommends for the setting up of National Rural Livelihood Mission (NRLM), rural livelihood fund and a hybrid model of both self-employment and wage employment. Therefore, based on the recommendations of RRC, GOI introduced NRLM by restructuring SGSY. The guiding principle of NRLM ensures that poor have a strong desire and innate capabilities to come out of poverty.

In a developing country like India, poverty is caused by interdependencies of various factors. For example, lack of ample income restricts rural people to invest in their children's education. Due to lack of better educational facilities, children fail to compete with others in getting jobs; which forces them to be satisfied with a job of low income. With that low income, it becomes difficult on their part to manage their family. They too become unable to provide better education and better food to their children. Therefore, they remain vulnerable. Therefore, in addressing the poverty (in India) anti-poverty programme here should be from a cycle of poverty perspective and should (i) provide varieties of services, (ii) go for collaboration among different organisations for providing complementary services and (iii) organise communities (Bradshaw, 2007).

NRLM is a livelihood promotion type intervention introduced by GOI by restructuring SGSY. The restructuring of the programme changed the strategy from allocation based to demand based. The latter provides states to develop their own poverty action plans; that help in alleviating poverty to a greater extent. Further, changes happened in the context of choosing the target group and financing under the programme. The target group for NRLM are chosen on the basis of participatory identification of poor instead of choosing from Below Poverty Line (BPL) list (used in the case of SGSY); due to a large number of inclusion and exclusion errors involved in the BPL list. Further, instead of providing one-time financial support (as provided in SGSY), the current programme ensures in providing financial assistance till attaining sustainable livelihoods with a keen eye on the utilisation of funds received; which was missing in SGSY. In addition to the above, the programme too provides self-employment training for the beneficiaries (RBI, 2013). The current programme does not provide subsidy to the beneficiaries, rather provides 
interest subvention. That means, if one SHG repays the loan amount for twelve months without any default, then the rate of interest paid by the SHG over and above $7 \%$ will be deposited in their bank account.

The above description clears that NRLM addresses poverty by adhering to the cyclical theory of poverty and provides varieties of services (both financial and non-financial), collaborates with other organisations for training and also organises the communities. Therefore, it is assumed to achieve its objectives to a greater extent in comparison to previous programmes. In a nutshell, NRLM is well equipped to provide sustainable livelihood to the poor through its services.

\section{References:-}

1. Badodiya, S.K., Tomar, S., Patel, M.M., \&Daipuria, O.P. (2012). Impact of Swarnajayanti Gram SwarozgarYojana on poverty alleviation, Indian Res.J. Ext. Edu, 12(3), 37-41.

2. Bagchee, S.(1987). Poverty alleviation programmes in seventh plan an appraisal, Economic and Political Weekly, 22(4), January 24, p 139.

3. Bradshaw, T.K. (2007). Theories of poverty and anti-poverty programmes in community development, Community Development, 38(1), 7-25.

4. Dasgupta, R. (2009). SGSY: Need for a paradigm shift, Economic and Political weekly,44(43).

5. Desai, A. R. (1987). Rural development and human rights in independent India, Economic and Political weekly, 22(31), p.1293.

6. Dhakad, S.S., \&Khedkar, N. S. (2014). Influence of seed-cum -fertilizer drill machine on growth characters and yield of Soyabean (Glycinemax L.) at farmer's fields, International Journal of Forestry and Crop Improvement, $5(2), 68-72$.

7. Government of India (1985). Report of the committee $t$ review the existing administrative arrangements for rural development and poverty alleviation programmes, Ministry of Agriculture, Department of Rural Development.

8. Haragopal, G., \&Balaramulu, C.H. (1989). Poverty alleviation Programmes: IRDP in an Andhra Pradesh district, Economic and Political Weekly, 24(35/36).

9. Hirway, I. (1985). Garibihatao: can IRDP do it? Economic and Political Weekly, 20(13), March 30, p 562.

10. Kalpana, K.(2011). Subverting policy, surviving poverty: women and the SGSY in rural Tamil Nadu, Economic and Political Weekly, 46(43), October 22.

11. Krishna, R. (1983). Growth, investment and poverty in sixth plan, Economic and Political Weekly, 18(47), November 19, p 1976.

12. Meshram, V., Pyasi, V.K., \&Saxena, V.K. (2005). Impact of Swarnajayanti Gram SwarogarYojana on beneficiaries of Mandla district, M.P., Indian Res. J. Ext. Edu., 5(2\&3), 148-149.

13. Mosse, D (2004): Is Good Policy Un implementable? Reflctions on the Ethnography of Aid Policy and Practice, Development and Change, 35(4): 639-71.

14. Paul, S. (1984). Mid-term appraisal of sixth plan- why poverty alleviation lags behind, Economic and Political Weekly, 19(18), May 5.

15. Ramreddy, G., and HarGopal, G. (1984). Public policy and rural poor in India, Concept publication and centre for economic \& social studies, Hyderabad.

16. Ramreddy, G., and HarGopal, G. (1985). The pyraveekar: the rural fixer, Asian survey, 25(11).

17. Ray, S. (2008). Alleviating poverty through micro-finance: SGSY experience in Orissa, Sociological Bulletin, 57(2), 211-239.

18. Reserve Bank of India (2013). Priority Sector Lending- Restructuring of SGSY as National Rural Livelihood Mission (NRLM), available at https://www.rbi.org.in/Scripts/NotificationUser.aspx?Id=8075\&Mode=0 (accessed on 25 December 2015).

19. Robinson, M.S. (2001). The microfinance revolution: Sustainable finance for the poor, The World Bank, Washigton, DC.

20. Sanwal, M. (1985). Garibihatao: Improving implementation, Economic and Political Weekly, 20(49), December 7, p 2177.

21. Subbarao, K. (1985). State policies and regional disparity in Indian agriculture, Development and Change, 16 (4), 523-546.

22. Yesudian, C. A. K. (2007). Poverty alleviation programmes in India: A Social audit, Indian Journal of Medical Research, October, 364-373. 